\title{
Addressing the Cognitive and Affective Domain of Ethics Across the Civil and Environmental Engineering Curriculum
}

\section{Dr. Jennifer Mueller PE P.E., Rose-Hulman Institute of Technology \\ Dr. Matthew D. Lovell, Rose-Hulman Institute of Technology}

Matthew Lovell is an Associate Professor in the Civil Engineering Department at Rose-Hulman Institute of Technology, and he currently serves as the Interim Senior Director of Institutional Research, Planning, and Assessment office. He is also serving as the director of the Making Academic Change Happen $(\mathrm{MACH})$ program. He received his Ph.D. from Purdue University, and he holds his PE license in Indiana. Matt is very active with respect to experimentation in the classroom. He greatly enjoys problem-based learning and challenge-based instruction. Matt is the 2018 recipient of the American Concrete Institute's Walter P. Moore, Jr. Faculty Achievement Award. He was awarded Teacher of the Year for the Illinois Indiana section of ASEE in 2017. Also, he was awarded the Daniel V. Terrell Outstanding Paper Award from ASCE. Matt is highly active in ASEE, currently serving as the ASEE CE Division's Freshman Director. In 2014, Matt received the ASEE CE Division Gerald R. Seeley Award for a paper highlighting a portion of his work regarding the development of a Master's Degree at Rose-Hulman.

Dr. Michael Robinson P.E., Rose-Hulman Institute of Technology

Michael Robinson is an Associate Professor of Civil and Environmental Engineering at Rose-Hulman Institute of Technology. 


\title{
Addressing the Cognitive and Affective Domain of Ethics Across the Civil and Environmental Engineering Curriculum
}

\begin{abstract}
As opposed to a single course or module on engineering ethics in professional practice, our approach to develop stronger learning outcomes is to weave threads of learning for each outcome through the civil and environmental engineering curriculum. With this approach, learning occurs not within a single course but across several courses spanning the four-year curriculum. Our threads of learning approach allows faculty to teach ethical decision making in courses not traditionally associated with ethics and provides students a more continuous exposure to ethical decision making. Students are introduced to the Civil Engineering Ethics Thread (CEET) at the very start of their academic career during fall quarter of freshman year. Students are given a brief introduction to the concept of the ethical thread of learning. At that time, they also complete a personality assessment, as well as a survey to rate their perception of what is ethical when given a variety of scenarios, to identify their own set of personal values. At the end of the quarter, the survey results are revealed to students for the purpose of recognizing the diversity of personal values among peers. Students delve further into ethical decision making in the context of academic integrity during the first year with reflections on real-life scenarios.

During the second year, students discuss the need for a purpose of a common set of ethical standards and review the American Society of Civil Engineers' Code of Ethics when interpreting ethical dilemmas. Students were introduced to an ethical decision-making process during fall of their junior year. This process is a step-by-step guide that includes reflection throughout the process of assessing and making a judgment on an ethical dilemma. During each quarter of junior and senior year, students were given a real-life ethical dilemma, and they utilized the given decision-making process to analyze their outcome of the dilemma. Cognitive assessment of student learning involved pre- and post-surveys at the beginning and end their four-year academic careers in the civil and environmental engineering curriculum that included perceptions on ethics of a given scenario, as well as personal ability to achieve learning outcomes. Direct assessment will also performed on written submissions of student reflections and analyses of ethical dilemmas through the ethical decision-making process. Assessment of affecting learning was performed through voluntary acknowledgment of personal behaviors and practices along a spectrum of ethical interpretation. Thus far, we have collected baseline survey data prior to the implementation of our approach.
\end{abstract}

\section{Introduction}

Efforts to integrate the teaching of knowledge / skills across a curriculum are wide spread across many institutions with efforts such as Writing Across the Curriculum being undertaken since the early 1970's [1]. A "pervasive method” of teaching ethics to law students was described by Link [2] where every professor in every course at the Notre Dame Law School would include ethics in their course. Each course, thereby, served a dual purpose: the teaching of law as well as the teaching of ethics. Ethics was to be spread widely - be pervasive - throughout the law curriculum. Refining this pervasive approach, Davis [3] described a method called "micro- 
insertion" where knowledge / skills can be added to a course without "substantial change in the course and in a way students appreciate.” Although both Link [2] and Davis [3] focused on teaching ethics, micro-insertion is appropriate for many topics that engineering departments struggle to find time within their curriculum to teach.

Micro-insertion is a teaching method that introduces concepts in micro-portions. Unlike standalone courses and teaching modules the micro-portions are introduced into a course as to have negligible impact on the time taken away from traditional topics. While micro-insertion has been used to broadly describe an approach where new content is added to an existing course [4], the micro-insertion approach proposed occurs at an even smaller scale. The work of Davis on microinsertion in both the classroom and laboratory has been funded by the National Science Foundation (NSF) over the last twenty years. His work has led to at least one textbook [5] adopting the micro-insertion approach to incorporate ethical decision making into the end-ofchapter problems.

Micro-insertion inserts new content at the micro-scale of a course. For example, Riley et al. [6] describe how ethics can be micro-inserted into a course by expanding the context of technical homework problems. A traditional calculation-based problem would be expanded by asking the student to evaluate an ethics issue based on their calculation. An instructor hesitant to sacrifice a portion of their course to an unrelated topic is more likely to adopt micro-insertion when shown that properly utilized the approach takes minimal time away from their schedule.

\section{Implementation Plan}

The Civil Engineering Ethics Thread (CEET) at Rose-Hulman Institute of Technology was first incorporated into the first-year curriculum during the 2015-16 academic year. During the 201617 academic year, content was incorporated into second-year courses. Threads of learning were implemented in third- and fourth-year courses during the 2017-18 and 2018-19 academic years, respectively.

Year 1:

By the end of Year 1, students should be able to:

- Identify their own set of personal values

- Distinguish between their personal values and the personal values of their peers

- Interpret the role of personal values with regard to the thoughts and behaviors of themselves and their peers

During the first week of fall quarter freshman year, students are given an assignment in a required surveying course. As part of this first CEET assignment, students complete a survey regarding individual opinions and perspectives relating to ethics, in addition to a personality questionnaire. The purpose of the this first assignment is to increase students' awareness and appreciation of different personal value systems. The Ethics Position Survey [7] presents 20 statements in which students agree or disagree with each statement on a 9-point Likert scale. Statements present commonly held opinions to which students rate their reactions. Responses include a range of reactions that demonstrate differences in personal value systems. Additionally, students complete a personality assessment to help recognize and increase their appreciation of other personality 
types. Survey results are then presented to students during a required Geographical Information Systems (GIS) course during winter quarter freshman year. Through an in-class discussion, students reflect on the variation in the spectrum of responses that demonstrate differences in personal value systems. Students are given two assignments in which they interpret and reflect upon a scenario involving eminent domain and academic misconduct. The academic misconduct assignment involves two anonymous testimonials by alumni of the department that committed acts of academic misconduct as students. During a required statics course in the spring quarter, students are introduced to the ASCE Code of Ethics. Based on their own set of personal values and the ASCE Code of Ethics, student reflected on a case that questions academic integrity.

Year 2:

By the end of Year 2, students should be able to:

- Explain the purpose of having an established ASCE Code of Ethics

- Paraphrase the canons the ASCE Code of Ethics

- Interpret ethical dilemmas in the context of ASCE Code of Ethics

During a required dynamics course, students examined the ASCE Code of Ethics and the historical context of how it developed. Students used the ASCE Code of Ethics to interpret an ethical dilemma by identifying which canons in the Code were violated, discussing the difference between negligence and a mistake, and examining grey areas of the Code.

Year 3:

By the end of Year 3, students should be able to:

- Describe a formal process for ethical decision making

- Apply an ethical decision-making process to resolve a win/no-win ethical dilemma During a required structural mechanics course in the fall quarter, students were introduced to an ethical decision-making process. Modified from the SIRA framework [8] for applying Reflexive Principlism [9], the following process describes the steps to thoroughly assess an ethical dilemma before making a decision and providing justification for that decision. Student submissions included documentation of each step.

1. Identification - Provide a brief factual narrative of the situation. Identify the dilemma and the basic ethical principles relevant to the ethical dilemma.

2. Perspective Taking - Identify relevant stakeholders and justify why they are relevant when considering this dilemma.

3. Develop Options - Identify as many responses to the dilemma as possible. Remember the "do nothing" option.

4. Explore Options - For each option, anticipate the likely impact on each of the stakeholders. Identify likely positive and/or negative impacts from the perspective of each stakeholder for each of the four basic ethical principles.

5. Reflection - Identify relevant values based on personal, societal, and professional value systems to evaluate the options.

6. Justification -State the decision that was reached. Justify the chosen decision and describe any implications of this decision based on Codes of Ethics and the four ethical principles. Include how decision aligns with personal, societal, and professional values. The ethical dilemma assessed in the structural mechanics course related to a "bouncing dance floor" in hotel that management acknowledged but had not done anything to address the problem. Students used the ethical decision-making process to determine a course of action, in 
addition to determining deflection of the structure. This ethical decision-making process was also apply ethical dilemmas given as assignments in a required construction engineering course during the winter quarter and an environmental engineering course during the spring quarter.

Year 4:

By the end of Year 4, students should be able to:

- Analyze a no-win ethical dilemma

- Analyze a dispute involving multiple conflicting ethical principles

- Discuss how ethics played a role in their senior design project

During the year-long senior capstone design course, students assessed two different ethical dilemmas. One dilemma involved an engineer being asked to donate engineering services to maintain future work for his firm (a no-win ethical dilemma). The students also analyzed the Deepwater Horizon Oil Spill case, in which there were conflicting ethical principles. For both case studies, students utilized the ethical decision-making process worked in teams to discuss the dilemma, reflect on relevant values and potential impacts of different options, and justify their decision. Documentation of this process was submitted as a group assignment for each team.

\section{Assessment Plan}

Cognitive assessment of student learning involved pre- and post-surveys at the beginning and end their four-year academic careers in the civil and environmental engineering curriculum. In one survey, students were asked to provide responses that represented their perceptions and opinions on ethics of 20 different statements using the Ethics Position Survey [7], as described in the previous section. This survey will be used for longitudinal assessment to track potential changes in student opinions within a cohort. The second survey had three parts: rating personal ability to achieve each learning outcome, rating the importance of ethics and other knowledge and skill sets for professional engineers, and rating the level to which they agree or disagree to statements relating to service and societal impacts on a macro-level of ethical considerations in the engineering profession. These surveys were administered at the start of fall quarter of freshman year and at the end of spring quarter of senior year to assess cognitive development in ethics and ethical decision making over the four-year curriculum.

Assessment of affecting learning was performed through voluntary acknowledgment of personal behaviors and practices along a spectrum of ethical interpretation. These surveys were completed on scantron forms to ensure anonymity and were administered at the end of each academic year.

Plans for direct assessment include rating written submissions of student reflections and analyses of ethical dilemmas through the ethical decision-making process. These submissions will be taken from assignments in two first-year courses (GIS and Statics), one second-year course (Dynamics), three third-year courses (Structures, Construction Engineering, and Environmental Engineering), and two quarters of the senior capstone design course. Rubrics for ratings these submissions are currently being developed. 


\section{Baseline Results and Discussion}

Data presented here show survey responses prior to implementation of CEET. The baseline data are from a first-year cohort and a fourth-year cohort from the 2015-16 academic year. The data show how perceptions may change in a general sense from freshman to senior year, but this particular data set does not track changes for one cohort over time.

Students rated their level of agreement/disagreement with each statement based on their perceived ability to achieve each CEET learning objective (Table 1 ). The response options were: $1=$ Strongly Disagree, 2=Disagree, 3=Slightly Disagree, 4=Neutral, 5=Slightly Agree, 6=Agree, $7=$ Strongly Agree.

Table 1: Student responses of ability to achieve CEET learning outcomes

\begin{tabular}{|l|c|c|c|c|}
\hline & \multicolumn{2}{|c|}{$\begin{array}{c}\text { Start of Year 1: 2015-16 } \\
\text { (n= 29) }\end{array}$} & \multicolumn{2}{|c|}{$\begin{array}{c}\text { End of Year 4: 2015-16 } \\
\text { (n = 40) }\end{array}$} \\
\hline & Mean & $\begin{array}{c}\text { Standard } \\
\text { Deviation }\end{array}$ & Mean & $\begin{array}{c}\text { Standard } \\
\text { Deviation }\end{array}$ \\
\hline $\begin{array}{l}\text { I am able to identify my own set of personal } \\
\text { values. }\end{array}$ & 6.17 & 1.17 & 6.43 & 0.87 \\
\hline $\begin{array}{l}\text { I am able to distinguish between my } \\
\text { personal values and the personal values of } \\
\text { my peers. }\end{array}$ & 5.93 & 0.80 & 6.05 & 0.90 \\
\hline $\begin{array}{l}\text { I am able to interpret the role of personal } \\
\text { values with regard to the thoughts and } \\
\text { behaviors of myself and my peers. }\end{array}$ & 5.83 & 1.04 & 5.93 & 0.94 \\
\hline $\begin{array}{l}\text { I am able to explain the purpose of having } \\
\text { an established ASCE Code of Ethics. }\end{array}$ & 5.38 & 1.37 & 6.00 & 1.09 \\
\hline $\begin{array}{l}\text { I am able to paraphrase the canons the } \\
\text { ASCE Code of Ethics. }\end{array}$ & 4.38 & 1.47 & 4.78 & 1.21 \\
\hline $\begin{array}{l}\text { I am able to interpret ethical dilemmas in } \\
\text { the context of ASCE Code of Ethics. }\end{array}$ & 4.83 & 1.37 & 5.70 & 0.99 \\
\hline $\begin{array}{l}\text { I am able to describe a formal process for } \\
\text { ethical decision making. }\end{array}$ & 5.03 & 1.59 & 5.58 & 1.01 \\
\hline $\begin{array}{l}\text { I am able to apply an ethical decision- } \\
\text { making process to resolve a win/no-win } \\
\text { ethical dilemma. }\end{array}$ & 5.38 & 1.32 & 5.63 & 0.95 \\
\hline $\begin{array}{l}\text { I am able to analyze a no-win ethical } \\
\text { dilemma. }\end{array}$ & 5.45 & 1.06 & 5.15 & 1.19 \\
\hline $\begin{array}{l}\text { I am able to analyze a dispute involving } \\
\text { multiple conflicting ethical principle. }\end{array}$ & 5.55 & 1.45 & 5.53 & 1.01 \\
\hline
\end{tabular}

Although not statistically significant, student ratings do trend upward over the four-year curriculum, prior to implementation of CEET.

To assess how students view the importance of ethics and other related skill sets for their careers, they were asked to provide their opinion on the importance of different knowledge and skills for 
professional engineers (Table 2). The response options were: 1=Very Unimportant, 2=Unimportant, 3=Slightly Unimportant, 4=Neutral, 5=Slightly Important, 6=Important, 7=Very Important.

Table 2: Student opinions on the importance of difference knowledge and skills for professional engineers [10]

\begin{tabular}{|l|c|c|c|c|}
\hline & $\begin{array}{r}\text { Start of Year 1: 2015-16 } \\
\text { (n=29) }\end{array}$ & \multicolumn{2}{|c|}{$\begin{array}{c}\text { End of Year 4: 2015-16 } \\
\text { (n= 40) }\end{array}$} \\
\hline & Mean & $\begin{array}{c}\text { Standard } \\
\text { Deviation }\end{array}$ & Mean & $\begin{array}{c}\text { Standard } \\
\text { Deviation }\end{array}$ \\
\hline $\begin{array}{l}\text { Business skills (business knowledge, } \\
\text { management skills, professionalism) }\end{array}$ & 6.21 & 0.68 & 5.98 & 1.35 \\
\hline $\begin{array}{l}\text { Cultural awareness/understanding (of your } \\
\text { culture and those of others) }\end{array}$ & 6.48 & 0.99 & 6.03 & 1.14 \\
\hline $\begin{array}{l}\text { Ethics (ensuring all of your work follows } \\
\text { professional codes of conduct) }\end{array}$ & 6.24 & 0.95 & 6.38 & 1.05 \\
\hline Fundamental skills (math \& science) & 6.45 & 1.06 & 5.93 & 1.05 \\
\hline $\begin{array}{l}\text { Professional skills (communication, } \\
\text { contemporary issues, creativity, leadership, } \\
\text { lifelong learning, teamwork) }\end{array}$ & 6.10 & 1.26 & 6.63 & 0.81 \\
\hline $\begin{array}{l}\text { Societal context (how your work connects } \\
\text { to society and vice versa) }\end{array}$ & 6.52 & 0.63 & 6.25 & 0.81 \\
\hline $\begin{array}{l}\text { Technical skills (design, problem solving, } \\
\text { conducting experiments, data analysis, } \\
\text { engineering tools) }\end{array}$ & 6.10 & 0.90 & 6.23 & 0.92 \\
\hline $\begin{array}{l}\text { Volunteerism (for professional and } \\
\text { personal reasons) }\end{array}$ & 4.55 & 1.62 & 5.45 & 1.08 \\
\hline
\end{tabular}

Students were asked to rate their level of agreement/disagreement with various statements relating to macro-level ethical considerations as professional engineers (Table 3). The response options were: 1=Strongly Disagree, 2=Disagree, 3=Slightly Disagree, 4=Neutral, 5=Slightly Agree, 6=Agree, 7=Strongly Agree.

Table 3: Student responses to various statements relating to macro-level ethical considerations [10]

\begin{tabular}{|l|c|c|c|c|}
\hline & $\begin{array}{c}\text { Start of Year 1: 2015-16 } \\
(\mathrm{n}=29)\end{array}$ & \multicolumn{2}{|c|}{$\begin{array}{c}\text { End of Year 4: 2015-16 } \\
\text { (n= 40) }\end{array}$} \\
\hline & Mean & $\begin{array}{c}\text { Standard } \\
\text { Deviation }\end{array}$ & Mean & $\begin{array}{c}\text { Standard } \\
\text { Deviation }\end{array}$ \\
\hline $\begin{array}{l}\text { I feel called by the needs of society to } \\
\text { pursue a career in engineering }\end{array}$ & 3.17 & 1.73 & 4.95 & 1.60 \\
\hline $\begin{array}{l}\text { I would not change my design if it } \\
\text { conflicted with community feedback }\end{array}$ & 6.31 & 0.60 & 3.15 & 1.46 \\
\hline $\begin{array}{l}\text { It is important for engineers to consider the } \\
\text { broader potential impacts of technical } \\
\text { solutions to problems }\end{array}$ & 5.90 & 1.21 & 6.00 & 1.01 \\
\hline
\end{tabular}




\begin{tabular}{|l|c|c|c|c|}
\hline $\begin{array}{l}\text { It is important to incorporate societal } \\
\text { constraints into engineering decisions }\end{array}$ & 3.28 & 1.65 & 5.95 & 1.13 \\
\hline $\begin{array}{l}\text { Service should not be an expected part of } \\
\text { the engineering profession }\end{array}$ & 4.97 & 1.43 & 3.05 & 1.62 \\
\hline $\begin{array}{l}\text { It is important to me personally to have a } \\
\text { career that involves helping people }\end{array}$ & 6.27 & 0.77 & 5.68 & 1.35 \\
\hline
\end{tabular}

Survey results shown here are inconclusive because they do not represent longitudinal change of a particular cohort, so personal opinions seem to have a greater influence than academic development.

\section{Conclusion}

As ethical decision-making is essential to our students' careers as civil and environmental engineers, we are hopeful that the combination of cognitive and affective development through CEET will prove to be beneficial. A more continuous exposure to ethics from within the department creates a better opportunity to enhance students' affective development. We desire our students to not only know about ethical decision-making but to value and even characterize themselves as ethical decision makers. Such affective development may lead to a culture within the student body characterized by a high standard of ethical behavior.

The use of CEET as an effective approach to teach ethics is not without challenges. The learning "touch points" occur within courses taught by different faculty. The development and acceptance of a both a common vocabulary and acceptable ethical decision-making process was necessary to present a uniform message to students. As an example, faculty had to agree upon the definition of and the distinctions between ethics and morals. These activities required a time commitment on part of the individual faculty and the department.

Unlike traditional courses that are the responsibility of faculty to manage, the ethical thread is the responsibility of the department, or a subset of the department. This diffusion of responsibility can make course management of the ethical thread challenging. Despite these challenges, we believe CEET will yield beneficial results as our students move through the thread.

\section{References}

[1] Russell, D. R. (1990). "Writing across the curriculum in historical perspective: Toward a social interpretation.” College English, 52(1), 52-73.

[2] Link, D. (1989) “The pervasive method of teaching ethics.” Journal of Legal Education, 39(4), 485-489.

[3] Davis, M., (2006) “Integrating ethics into technical courses: micro-insertion.” Science and Engineering Ethics, 12(4), 717-730.

[4] Brouwer R., VanderLeest, S., Ribeiro, P., Medema, R. (2010) "Leveraging the unique character of a general engineering program to enhance students' entrepreneurial mindset," Proceedings of the 2010 American Society for Engineering Education (ASEE) Conference, Louisville, KY, June, 2010. 
[5] Vesilind, A. and Morgan, S. (2004). Introduction to Environmental Engineering, $2^{\text {nd }}$ Ed. Brooks/Cole - Thomson, Belmont, California.

[6] Riley, K., Davis, M., Cox, A. and Maciukenas, J. (2007). "Ethics in the details: an NSF project to integrate ethics into the graduate engineering curriculum.” Proceedings of the Professional Communication Conference, IEEE International. October 1-3, 2007 Seattle, Washington.

[7] Forsyth, D. R. (1980). A taxonomy of ethical ideologies. Journal of Personality and Social Psychology, 39(1), 175-184.

[8] Kisselburgh L, Zoltowski CB, Beever J, Hess JL, Iliadis AJ, Brightman AO. (2014) “Effectively engaging engineers in ethical reasoning about emerging technologies: A cyber-enabled framework of scaffolded, integrated, and reflexive analysis of cases.” ASEE Annual Conference and Exposition, Conference Proceedings.

[9] Beever, J. \& Brightman, A.O. (2016). "Reflexive Principlism As An Effective Approach for Developing Ethical Reasoning in Engineering.” 2016 [online Feb 2015]. Science and Engineering Ethics 22(1):275-291.

[10] McCormick, M. Bielefeldt, A.R., Swan, C.W., and Paterson, K.G. (2015). Assessing students' motivation to engage in sustainable engineering. International Journal of Sustainability in Higher Education 16(2): 136-154. DOI 10.1108/IJSHE-06-2013-0054. 